\title{
THE EFFECT OF SUBSTITUENTS IN THE MOLECULES OF N-, R-ALKYL AMINES ON SOME GRAM-POSITIVE STRAINS OF MICROORGANISMS
}

\author{
M.Yu.Golik, N.A.Komissarenko, S.G.Leonova, T.P.Osolodchenko \\ National University of Pharmacy \\ State Institution "Institute of Microbiology and Immunology named after I.I.Mechnikov \\ of the National Academy of Medical Sciences of Ukraine" \\ Key words: $N$-, R-alkylamines; antimicrobial activity
}

\begin{abstract}
The intensive use of antibiotics in patient care institutions often without determining specificity and sensitivity to them leads to more rapid development of resistance to pathogens of nosocomial infections; that is why it is one of the urgent problems of healthcare of Ukraine. The most common gram-positive pathogens of nosocomial infections are Staphylococcus aureus, coagulase-negative staphylococci and enterococci. In order to determine dependence of the microbiological action on the nature of substituents in the molecules of $\mathrm{N}$-, R-alkylamines some methyl, ethylamine, aminoalcohols, $\mathrm{N}$-hydroxymethyl- and $\mathrm{N}$-methyl-N-carboxymethylamines have been tested. In accordance with the WHO recommendations to assess the antibacterial activity of $N$-, $R$-alkylamines the gram-positive test strains - Staphylococcus aureus ATCC 25923 and Bacillus subtilis ATCC 6633 were used. The aliphatic amines and aminoalcohols studied show a weak or moderate activity in relation to strains of Staphylococcus aureus ATCC 25923 and Bacillus subtilis ATCC 6633. Compounds containing a carboxyl group and methyl radicals in the molecule exhibit the greatest antimicrobial activity in relation to the gram-positive strains of microorganisms under research.
\end{abstract}

Antibacterial agents are practically the only group of drugs which effectiveness decreases with time due to development of resistance. The intensive use of antibiotics in patient care institutions often without determining specificity and sensitivity to them leads to more rapid development of resistance to pathogens of nosocomial infections; that is why it is one of the urgent problems of healthcare of Ukraine. The main factors that contribute to the increased disease incidence are: shortage of medicines, antiseptics, detergents and disinfectants, medical instruments, linen, sterilization equipment since medical preventive institutions are forced to work in conditions of the extremely limited funding; a significant growth in the number of hospital strains that are resistant to antibiotics and disinfectants, etc. [4].

The most common gram-positive pathogens of nosocomial infections are Staphylococcus aureus, coagulase-negative staphylococci and enterococci. The results of the multicentre randomized trial SCOPE (USA) published in 2004 indicate the predominance of gram-positive cocci in the etiological structure of nosocomial bacteriemias [14].

This tendency creates significant problems since the choice of antimicrobial agents intended to combat drugresistant gram-positive microorganisms is limited. It should be also noted the fact that antibiotics are less than 5\% of the drugs being currently at the stage of drug development [5], and as resistance to the medicines used develops, there is a need in both creation of new drugs, and correction of methods for using the existing ones. Therefore, the research in development of drugs, including vaccines and diagnostic agents, are of vital importance for protection of future generations.

It is known that tertiary amine salts or quaternary ammonium bases containing radicals with a large number of carbon atoms exhibit a strong bacteriostatic and bactericidal action, as well as possess pronounced disinfectant properties $[1,8]$. In literature there are data that compounds with the number of carbon atoms from 5 to 16 are the most effective against microorganisms [6].

The aim of this work was to determine the effect of various functional groups containing in the molecules of $\mathrm{N}$-, R-alkylamines derivatives on their antibacterial activity in relation to some gram-positive strains of microorganisms.

\section{Materials and Methods}

In order to determine dependence of the microbiological action on the nature of substituents in the molecules of N-, R-alkylamines the following groups were tested: alkylamines (compounds I-VI), aminoalcohols (compounds VII-IX), N-hydroxymethyl-N-carboxymethylamines (compounds X-XII), and N-methyl-N-carboxymethylamines (compounds XIII-XV) (see Table).

The compounds under research were obtained from commercial sources or synthesized according to the synthetic schemes previously developed [2, 3, 6, 9, 11-13]. Reagents were purchased from "Sigma-Aldrich" (USA) and used without further purification. 1\% Aqueous solutions of compounds I-XV were tested.

In accordance with the WHO recommendations to assess the antibacterial activity of N-, R-alkylamines the gram-positive test strains - Staphylococcus aureus 
Table

Data of the study results of the antibacterial activity of $1 \%$ solutions of the samples under research

\begin{tabular}{|c|c|c|c|}
\hline \multirow[b]{2}{*}{ Compound } & \multirow[b]{2}{*}{ The structural formula } & \multicolumn{2}{|c|}{ Test strains/inhibition zones, $\mathrm{mm}$} \\
\hline & & $\begin{array}{c}\text { Staphylococcus aureus } \\
\text { ATCC } 25923\end{array}$ & $\begin{array}{c}\text { Bacillus subtilis } \\
\text { ATCC } 6633\end{array}$ \\
\hline I & $\mathrm{H}_{2} \mathrm{~N}-$ & 10 (I.s.) $)^{*} \pm 0.1$ & 10 (I.s.) \pm 0.1 \\
\hline II & $-\mathrm{N}^{-}$ & 10 (I.s.) \pm 0.1 & 10 (I.s.) \pm 0.1 \\
\hline III & & 15 (I.s.) \pm 0.1 & 15 (I.s.) \pm 0.1 \\
\hline IV & & 10 (I.s.) \pm 0.1 & 10 (I.s.) \pm 0.1 \\
\hline $\mathrm{V}$ & & 12 (I.s.) \pm 0.1 & 10 (I.s.) \pm 0.1 \\
\hline VI & & 10 (I.s.) \pm 0.1 & 10 (I.s.) \pm 0.1 \\
\hline VII & $\mathrm{H}_{2} \mathrm{~N}$ & 10 (I.s.) \pm 0.1 & 10 (l.s.) \pm 0.1 \\
\hline VIII & $\mathrm{HO}^{-}$ & 13 (I.s.) \pm 0.1 & 10 (I.s.) \pm 0.1 \\
\hline IX & & 20 (s.) \pm 0.2 & 21 (s.) \pm 0.2 \\
\hline$x$ & & 20 (s.) \pm 0.2 & 17 (s.) \pm 0.2 \\
\hline$X I$ & & 20 (s.) \pm 0.2 & 25 (s.) \pm 0.2 \\
\hline XII & $\mathrm{Cl}^{-}$ & $21(\mathrm{~s}) \pm 0.2$. & 25 (s.) \pm 0.2 \\
\hline XIII & & 40 (h.s.) \pm 0.3 & 39 (h.s.) \pm 0.3 \\
\hline XIV & & 40 (h.s.) \pm 0.3 & 39 (h.s.) \pm 0.3 \\
\hline $\mathrm{XV}$ & $\mathrm{Cl}^{-}$ & 42 (h.s.) \pm 0.3 & 39 (h.s.) \pm 0.3 \\
\hline
\end{tabular}

* Note: I.s. - low sensitivity of the culture to the given concentration of the test substance; s. - sensitivity of the culture to the given concentration of the test substance; h.s. - high sensitivity of the culture to the given concentration of the test substance.

ATCC 25923 and Bacillus subtilis ATCC 6633 were used. The suspension of the test microorganism was prepared according to the method [10]. Standardization of the bacterial suspension of microorganisms prepared was carried out using a Densi-La-Meter device (manufactured by PLIVA-Lachema, Czech Republic). Synchronization of cultures by changing the cultivation temperature was achieved with a single effect of low temperature $\left(4^{\circ} \mathrm{C}\right)$. Microbial load was $10^{7}$ microbial cells per $1 \mathrm{ml}$ of the medium and set up according to McFarland standard. We worked with 18-24 hour culture of microorganisms.

For studies Mueller-Hinton agar ("HIMedia Laboratories, Pvt. Ltd India" the shelf life of the medium to XI 2016, manufactured by India) was used.

Diffusion of the drug into the agar was conducted by the "wells" method [7]. When assessing the activity 
of compounds I-XV, as well as when studying antibiotic-resistant strains the following criteria were used:

- the absence of inhibition zones of microorganisms around the well, the diameter of the inhibition zone to $10 \mathrm{~mm}$ indicates that the organism is insensitive to the drug introduced into the well or to the antibiotic concentration;

- inhibition zones with the diameter of 10-15 mm indicate a low sensitivity of the culture to the given concentration of the test substance;

- inhibition zones with the diameter of 15-25 $\mathrm{mm}$ assessed as an indicator of the sensitivity of a microorganism to the test substance;

- inhibition zones, which diameter exceeds $25 \mathrm{~mm}$, indicates the high sensitivity of microorganisms to the test substance.

\section{Results and Discussion}

A low sensitivity of the set of microorganisms used to the action of aliphatic amines I-VI was determined. The antimicrobial activity of aminoalcohols VII-IX was slightly higher, and its enhancement is observed with increasing the number of hydroxyethylene radicals in the molecule. Compounds X-XII containing a carboxyl and hydroxymethyl group in the molecule was more active, with the increasing number of hydroxyethylene groups the inhibition zones were 20-21 mm for Staphylococcus aureus and 17-25 mm for Bacillus subtilis.

Compounds containing a carboxyl group and methyl radicals appeared to be the most promising among the compounds tested. It is this combination of substituents that contributes to a high microbicide activity in relation to Staphylococcus aureus and Bacillus subtilis. Increase of the number of methyl radicals in the molecules of compounds XIII-XV leads to a significant increase in activity - the inhibition zones are 39-42 $\mathrm{mm}$.

CONCLUSIONS

1. The effect of various functional groups containing in the molecules of N-, R-alkylamines derivatives on their antibacterial activity in relation to some grampositive strains of microorganisms has been determined.

2. The aliphatic amines and aminoalcohols studied show a weak or moderate activity in relation to strains of Staphylococcus aureus ATCC 25923 and Bacillus subtilis ATCC 6633.

3. Compounds containing a carboxyl group and methyl radicals in the molecule exhibit the greatest antimicrobial activity in relation to the gram-positive strains of microorganisms under research.

\section{REFERENCES}

1. Антисептики в профилактике и лечении инфекций / Под ред. Г.К.Палия. - К.: Здоровье, 1997. - С. 108.

2. Бобков С.С., Смирнов С.К. Синильная кислота. - М.: Химия, 1970. - С. 172.

3. Вейганд - Хильгетаг. Методы эксперимента в органической химии / Пер. с нем. - М.: Химия, 1968. $944 c$.

4. Внутрибольничные инфекичи: проблемы и решения [Электронный ресурс] / Журнал «Заместитель главного врача»: интернет-журн. - 2008. - Bып. 6. - Режим достуnа: http://www.zdrav.ru/articles/practice/detail.php? ID=76435

5. Всемирная Организаичия Здравоохранения 2015. Европейское региональное бюро [Электронньй ресурс] Pежим достуnа: http://www.euro.who.int/ru/health-topics/disease-prevention/antimicrobial-resistance/antibiotic-resistance/frequently-asked-questions.

6. Глодников Г.В., Мандельштам Т.В. Практикум по органическому синтезу. - Л.: Изд-во Ленинградского университета, 1976. - C. 372.

7. Державна фармакопея Украӥни / Державне підприємство «Науково-експертний фармакопейний центр». 1-е вид. - Х.: РІРЕГ, 2011. - Доп. 4. - 536 с.

8. Практическое руководство по биологической безопасности в лабораторных условиях. 3-е изд. - Всемирная Организачия Здравоохранения. Женева, 2004. - 190 с.

9. Рабинович В.А., Хавин 3.Я. Краткий химический справочник. - 3-е изд., перераб. и доп. - Л.: Химия, 1991. $-432 c$.

10. Стандартизація приготування мікробних суспензій. Інформаційний лист про нововведення у системі охорони здоров'я України № 163-2006. - Київ, 2006.

11. Gallant R.W. // Hydrocarbon Processing. - 1973. - Vol. 52, №11. - P. 150.

12. Kirk-Othmer encyclopedia, 3-rd ed. - Vol. 1. - N.-Y., 1978. - P. 944.

13. Kirk-Othmer encyclopedia, 3-rd ed. - Vol. 2. - N.-Y., 1978. - P. 272-282.

14. Wisplinghoff H., Bischoff T., Tallent S.M. et al. // Clin. Infect. Dis. - 2004. - №39. - P. 309-317. 


\section{ВПЛИВ ЗАМІСНИКІВ В МОЛЕКУЛАХ N-, R-АЛКІЛАМІНІВ НА ДЕЯКІ ГРАМПОЗИТИВНІ ШТАМИ МІКРООРГАНІЗМІВ М.Ю.Голік, М.А.Комісаренко, С.Г.Леонова, Т.П.Осолодченко \\ Ключові слова: $N$-, R-алкіламіни; антимікробна активність}

Інтенсивне застосування антибіотиків у лікарських установах, часто без визначення специфріки та чутливості до них, призводить до більш швидкого розвитку стійкості до збудників внутрішньолікарняних інсрекцій, що є однією з актуальних проблем охорони здоров'я України. Найбільш розповсюдженими грампозитивними збудниками внутрішньолікарняних інфрекцій $\epsilon$ Staphylococcus aureus, коагулазонегативні стафрілококи та ентерококи. 3 метою встановлення залежності антимікробної дії від природи замісників в молекулах $N$-, $R$-алкіламінів були протестовані деякі метил-, етиламіни, аміноспирти, $\mathrm{N}$-гідроксиметил- та $\mathrm{N}$-метил- $\mathrm{N}$ карбоксиметиламіни. У відповідності до рекомендацій ВООЗ для оцінки антибактеріальної активності N-, R-алкіламінів використовували грампозитивні тест-штами Staphylococcus aureus ATCC 25923 ma Bacillus subtilis ATCC 6633. По відношенню до штамів Staphylococcus aureus ATCC 25923 ma Bacillus subtilis ATCC 6633 досліджувані аліфратичні аміни та аміноспирти виявляють слабку або помірну активність. Найбільшу антимікробну активність до досліджуваних грампозитивних итамів мікроорганізмів проявляють сполуки, що містять у молекулах карбоксильну групу та метильні радикали.

\section{ВЛИЯНИЕ ЗАМЕСТИТЕЛЕЙ В МОЛЕКУЛАХ N-, R-АЛКИЛАМИНОВ НА НЕКОТОРЫЕ ГРАММПОЛОЖИТЕЛЬНЫЕ ШТАММЫ МИКРООРГАНИЗМОВ \\ Н.Ю.Голик, Н.А.Комиссаренко, С.Г.Леонова, Т.П.Осолодченко \\ Ключевые слова: $N$-, R-алкиламины; антимикробная активность}

Интенсивное использование антибиотиков в лечебных учреждениях, зачастую без определения специфрики и чувствительности к ним, приводит к более быстрому развитию устойчивости к возбудителям внутрибольничных инфекций, что является одной из актуальных проблем здравоохранения Украины. Наиболее распространенными граммположительными возбудителями внутрибольничных инфекций являются Staphylococcus aureus, коагулазонегативные стафрилококки и энтерококки. С целью установления зависимости антимикробного действия om природы заместителей в молекулах $N$-, R-алкиламинов были протестированы некоторые метил-, этиламины, аминоспирты, $N$-гидроксиметил- и N-метил-N-карбоксиметиламины. В соответствии с рекомендациями ВОЗ для оценки антибактериальной активности N-, $R$-алкиламинов использовали граммположительные тест-итаммы - Staphylococcus aureus ATCC 25923 и Bacillus subtilis ATCC 6633. По отношению к штаммам Staphylococcus aureus ATCC 25923 и Bacillus subtilis ATCC 6633 исследуемые алифратические амины и аминоспирты проявляют слабую или умеренную активность. Наибольшую антимикробную активность к исследуемым граммположительным штаммам микроорганизмов проявляют соединения, содержащие в молекулах карбоксильную группу и метильные радикалы. 